\title{
Wage Collective Bargaining and Employee Voluntary Quits: A Romanian Empirical Analysis
}

Cristina Boboc, Oana Calavrezo *

Abstract:

In this paper, we analyze Hirschman's "voice-exit" theory on the Romanian labour market. In other words, we study the relationship between wage collective bargaining and employee voluntary departures. We assess a kernel matching estimator on a recent Romanian survey of 783 firms. We highlight that, in Romania, before the integration to the European Union, wage collective bargaining implies a weakly significant increase in the probability of experiencing voluntary separations. This result is contrary to the relationship found in empirical studies implemented on developed countries.

Keywords: Romania, wage collective bargaining, employee voluntary separation, propensity score matching estimation

JEL: J22, J3, J5

DOI: $10.2478 / \mathrm{v} 10033-010-0007-2$

\section{Introduction}

This paper investigates Hirschman's "voice-exit" theory on the Romanian labour market by analyzing the relationship between wage collective bargaining and employee voluntary departures in Romania in 2006. Up to now, Romanian wage collective bargaining has mainly been analyzed from a descriptive point of view. Our contribution is empirical. We want to check with Romanian data if (as found in the literature for developed countries) there is a negative relationship between collective bargaining and voluntary job quits. We implement a kernel matching estimator on a very recent and original dataset of 783 Romanian firms.

The International Labour Organisation (ILO) defines collective bargaining as "voluntary negotiations between employers or employers' organisations and workers' organisation with a view to the regulation of terms and conditions of employment by collective agreement" (ILO Convention $n^{\circ}$ 98). Collective bargaining is used as a method to improve terms and conditions of employment (wages, working time, training and education, safety, health and equal treatment).

The contribution of the present study lies in its analysis of the impact of wage collective bargaining on voluntary employee flows. We focus on voluntary employee turnover because it is a key concern for both Romanian firms and employees. Industry publications estimate annual turnover rates of between 22 and 50 percent worldwide. This can substantially raise recruitment and training costs and contribute to reduced service quality and productivity when firms lose experienced employees. High voluntary turnover rates may also indicate that employees are dissatisfied with pay and working conditions and in the long run can cause

\section{* Cristina Boboc}

University of Economics, Bucharest

Department of Statistics and Econometrics

E-mail: cristina.boboc@csie.ase.ro

\section{Oana Calavrezo}

University of Orléans -LEO

LEO, Faculté de Droit, d'Economie et de Gestion

E-mail: oana.calavrezo@etu.univ-orleans.fr 
individuals to lose pay and miss out on advancement opportunities (Cappelli and Neumark, 2004). Voluntary turnover is thus an important measure of how collective bargaining affects both labour costs and employee behaviour.

Some special features of the Romanian industrial relations system should be mentioned in order to understand the results of our work. We use data from the European Industrial Relations Observatory (EIRO). In Romania, the legal framework for collective bargaining is laid down in a particular law on collective agreements (law $n^{\circ} 130 / 1996$ on Collective Agreements). At the beginning of the $90 \mathrm{~s}$ most countries of Central and Eastern Europe introduced new labour laws which included the legal foundations for the creation of a new collective bargaining system. In Romania, we have the 2003 Labour Code. Data on the Romanian collective bargaining coverage is not available. Romania has a relatively decentralized bargaining system with company bargaining dominant. Collective bargaining at a national level sets national minimum pay and conditions which apply across the whole economy. Negotiations also take place in a substantial number of industries and companies. But it is only where trade unions are strong at the company level that significant improvements are negotiated. Overall the law provides detailed rules for collective bargaining. Union density is relatively high in Romania, between 30 and $35 \%$. The structures are fragmented with five separate confederations, each with a substantial number of affiliated structures which are very decentralized. Many local union groupings do not belong to any of the main confederations and where they do the links may be weak.

Collective bargaining in Romania does not appear to be similar to any particular country, although findings in other Central Eastern Europe countries revealed several comparable changes and continuities (Trif, 2005). In contrast to most Central Eastern Europe countries, in Romania employers are obliged to initiate collective bargaining process in all companies with more than 21 employees, and there is an extension mechanism at each level. Also, the perception of an increase of the State's influence on the terms of the conditions of employment after 1989 was not found in other Central Eastern Europe countries. Differences in collective bargaining among countries are likely to be determined to a certain extent by the dissimilarities in the legislation, national inherited legacies and progress with economic reforms (Aro and Repo, 1997; Clarke, Cremers and Janssen, 2003).
There is a well known theory linking the presence of organized labour in firms and employee flows. Freeman and Medoff (1979) and Freeman (1980) analyzed the effect of collective bargaining (trade unionism) on the exit behaviour of workers using the "voice" hypothesis. Freeman (1980) examined the effect of the presence of trade unions on the exit behaviour of workers using the dichotomy of "exit" and "voice" previously proposed by Hirschman (1970). Workers have two possibilities to express their discontent with their working conditions: either leave the firm (exit) or discuss their problem with their employer (voice). Collective bargaining can provide a voice for workers. Voice is embodied in the collective bargaining process to negotiate with the management, so when workers have the institution of a voice to express discontent they should quit the firm less frequently: an inverse relationship should be observed between collective bargaining (union presence) and voluntary worker mobility.

This result is found in several empirical papers on developed countries. We must nevertheless take into account the economic situation. Employees are less likely to quit their jobs when the unemployment rate is high, as their chances to find another job are reduced. OECD statistics show that countries with stronger employment protection legislation have lower levels of employee "churn" with less frequent job changes and longer spells of unemployment (OECD, 2004). For example, for the cases of the U.S. and Germany we find a negative relation between collective bargaining and voluntary job quits in the papers of Batt, Colvin and Keefe (2002), Backes-Geller, Frick and Sadowski (1997), Freeman (1980) and Frick (1996). In the same countries, in a very recent article Doellgast (2008) assesses the relationship between national and collective bargaining institutions, management practices and employee turnover in the U.S. and in Germany in call centres. She found that globally collective bargaining is associated with lower quit rates in both countries. Doellgast (2008) also emphasized that there can be possible differences in the strength of collective bargaining effects on turnover. On Spanish data Garcia-Serrano and Malo (2002) find the same result. They also study the impact of collective bargaining on job flows. An original point about our work is that excepting Frick(1996), Garcia-Serrano and Malo (2002) there is no analysis where the voice effect is present in labour markets with institutional settings that extend the results of collective bargaining to all workers, whether affiliated or not. Delery et al. (2000) found that union effects on 
quits disappeared when wages and benefits were included in the equation.

A theoretical study on Hirschman's "voice theory" in Central Eastern Europe was made in a recent paper by Meardi (2007). His analysis is not focused on the Romanian case (he concentrates his work on countries that entered the EU in 2004: Cyprus, the Czech Republic, Estonia, Hungary, Latvia, Lithuania, Malta, Poland, Slovakia and Slovenia) but this work may be interesting and useful in understanding our work. The distinction between what behaviour constitutes "exit" and what constitutes "voice" can be controversial, but a sound operationalization of these concepts is provided by Greskovits (1998). In the 1990s, Greskovits had noted how rather than strikes and riots, workers preferred exit from the labour market, protest voting and rent-seeking. Exit from the formal labour market includes the option for benefits, work in the informal sector and migration.

The increase of wages in the new entrant states of the UE is interestingly roughly inversely correlated to collective bargaining coverage. This means that formal industrial relations are not the driving force behind them. Wage increases are granted not because of the union power but because of exit threats (Meardi, 2007). For 2007, in Romania, national observers considered significant in terms of "voice" expression the following industrial relations events: strike threats at the sector level in mining for health and pay reasons and collective bargaining advances at the company level in the post sector for pay reasons. These events can be contrasted with a pure "exit" based model (EIRO).

The new member states show that even in the most favourable political conditions employment can not be ruled by pure market principles: "exit" strategies turn into labour problems which in turn call for "voice" solutions. Following Hirschman a strong "exit" at a given time prepares a strong voice later. The stricter limits to the freedom of movement of Romanian workers put this country in a different position from the previous accession countries. Exit is less visible and may occur more through informality (informal exit settlements between employees and employers) (Meardi, 2007).

The reminder of the paper is organized as follows. The second Section describes the data and the indicators. The third Section outlines the econometric approach. The forth Section presents the results and the fifth provides conclusions.

\section{Data and Indicators}

In order to analyze the effect of wage collective bargaining on employee departures within Romanian firms, we used a recent survey. The data were collected in 2006 by the Economic and Social Council of Romania in collaboration with the Romanian Ministry of Labour, Social Solidarity and Family. The survey is comprised of a national representative sample of 841 Romanian firms having at least 10 employees. Firms were chosen randomly from a database provided by the Romanian Commerce Registry Office. The originality of the survey is double: first, because it represents one of the few databases analyzing Romanian wage collective bargaining and second, because it contains a number of subjective questions concerning the opinions of Romanian employers.

The survey contains the following information: industry, firm size, geographical region of implementation, ownership, firm legal type, method for establishing wages, intensity of the effects of several national and branch collective bargaining agreements on the collective labour contracts, determinants of wage collective bargaining, evaluation in terms of performance of the workforce, firm size variation rate, employee voluntary separations and determinants of employee voluntary separations. We describe in detail only the variables used during the implementation of the econometric approach'.

In this paper we want to establish the impact of negotiating collectively wages on employees' voluntary departures. We create a dummy variable indicating if wages are established inside the firm by collective bargaining (coll_negociation $=1$ ) or if they are settled directly by the employers ( coll_negociation $=0$ ). The Romanian law imposes that all firms with at least 21 employees must develop a collective bargaining process, although they are not obliged to reach an agreement. So, even if in our sample firms with at least 21 employees are in the majority this does not imply that all of them negotiate wages collectively. They are only obliged to collectively bargain in general. For example, we can imagine that firms where wages are directly imposed by the employer negotiate collectively other points: working time duration, working conditions, etc.

\footnotetext{
${ }^{1}$ Appendix 1 presents all dummy variables used in this study.
} 
Our result variable gives the employers' opinions on voluntary departures from their firms. This indicator is binary: volunt_departure $=1$ if employers appreciate that during 2006 employees voluntarily left their firm and volunt_departure $=0$ otherwise.

The firm's industry is given initially at a two-digit level. We aggregate this information in ten classes (each one corresponding to a dummy variable): agriculture; extractive industry; manufacturing industry; electricity, gas and water supply industry; construction; trade; hotels and restaurants; transports; financial intermediation, real estate activities, research and development, operational services and consultancy and assistance and finally, other services (community, social and personal service activities, private households with employed persons, education, health and social work and extra-territorial organizations).

At the firm level, there is a legal obligation to negotiate - although not to reach agreement. The employer is required to initiate the process. This obligation applies where the company has 21 or more employees. As we want to emphasize this threshold of 21 employees, we work with four classes of size: between 10 and 20 employees, between 21 and 49 employees, between 50 and 249 employees and 250 employees and more.

The firm's geographical implementation is given at a four-digit level. We construct eight dummy variables indicating the location of the firm: the North-East region, the West region, the North-West region, the Centre region, the South-East region, the South-Muntenia region, the Bucharest-IIfov region and the South-WestOltenia region².

Regarding firms' ownership, we construct seven dummies: private firm with full Romanian capital, private firm with full foreigner capital, private firm with majority Romanian capital, private firm with majority Romanian capital with the rest belonging to the state, private firm with majority foreign capital, public firm with full state capital and public firm with majority state capital.

For the legal type of the firm, we have three dummies: a limited liability company, stock company and other forms. Concerning the firm's size variation rate, we have three dummies indicating if the size of the firm increased between 2004 and 2005: yes, no and it remained still. We also retained five dummies indicating the ways a firm

\footnotetext{
${ }^{2}$ See appendix 2 for a graphic display of the main eight Romanian regions.
}

evaluates the performances of its workforce: does not evaluate the performance of its workers, evaluates the performance for wage reasons, evaluates the performance for job promotion reasons, and evaluates the performance for both wage and job promotion reasons as well as other reasons.

After eliminating firms with missing values for the explanatory variables presented above, our final database contained 783 Romanian firms.

\section{Econometric Strategy}

Firms which negotiate their wages collectively can make the object of a non-random selection process concerning the wage collective bargaining phenomenon and even a process of auto-selection (if negotiating their wages collectively is considered an element of their internal strategy). This induces a selection bias. To circumvent the selection bias, we estimate evaluation models with matching estimators. They were initially developed by Rubin (1974) in order to study the efficiency of medical treatments. These models were mobilized in economics, in particular to test the efficiency of job training programs.

Let us denote by $T$ a binary variable indicating if the individual received treatment or not $(T=1$ if the individual is treated, $T=0$ if not). The efficiency of the treatment is measured through the result $y_{i}$. Thus, each individual has two potential results: $y_{0}$ (if $T=0$ ) and $y_{1}$ (if $T=1$ ). $y_{0}$ and $y_{1}$ are never observed simultaneously, since an individual either is treated, or untreated, but never both at the same time. In other words, only the true health of the individual, noted $Y$, is observed: $Y=y_{1} T+y_{0}(1-T)$.

Only the couple $(Y, T)$ is observed for each individual. Rubin (1974) defines the average treatment effect as the difference between what would be the health of an individual if he was treated and what it would be if he was not: $C=y_{1}-y_{0}$. The average treatment effect is unobservable and individual, and consequently its distribution is not identifiable. Under the independence property $\left(y_{0}, y_{1}\right) \perp T$ there is no selection bias.

In the majority of cases, the property of independence is not valid. A solution would be to compare the health of each individual who received the treatment with the health of an identical counterfactual who did not receive the treatment. To identify statistically the counterfactual, 
an approach consists in building a counterfactual population for which the distribution of a number of observable characteristics ( $X$ - matching variables) is the same as for the group receiving the treatment. Consequently, the property of independence is respected conditionally on observed matching criteria $\left(y_{0}, y_{1}\right) \perp T \mid X$. When many matching criteria must be taken into account in order to achieve conditional independence, finding a counterfactual can be problematic. Rubin and Rosenbaum (1983) solved this problem by showing that conditional independence with the $X$ variables was equivalent to independence given a propensity score. The propensity score constitutes a onedimension summary of the matching variables and it is an estimate of the probability of being exposed to the treatment, conditionally on these variables. There are several propensity score matching estimators. They differ not only in the way the neighbourhood for each treatment individual is defined and the common support is handled, but also with respect to the weights assigned to these neighbours. Excepting kernel estimators, we have globally the following matching methods: nearest neighbour matching, calliper and radius matching and stratification and interval matching. The performance of different matching estimators varies case-by-case and depends largely on the data structure at hand (Zhao, 2000). In this work, we use the kernel estimator of Heckman, Ichimura and Todd (1998). More precisely, we use an Epanechnikov kernel $\left(F(u)=\frac{3}{4}\left(1-|u|^{2}\right)\right.$ if $|u| \leq 1$ and $F(u)=0$ otherwise) with a bandwidth selection criterion developed by Silverman ( $h_{j}=1.364 \sigma_{s_{j}} n_{j}^{-1 / 5} 15^{1 / 5}$, where $\sigma_{s_{j}}$ is the standard error of the propensity score for the control group and $n_{j}$ is the number of individuals inside the control group). For the calculation of the kernel estimator for the treated, each non-treated individual takes part in the construction of the counterfactual of the treated individual. The weight of the non-treated in the constitution of the counterfactual is given according to the distance between their score and the score of a treated individual. In order to calculate the standard error for the kernel estimator we implement a bootstrap technique (1000 draws).

In this paper we work with two categories of firms: firms where wages are negotiated collectively and firms which do not negotiate collectively their wages. The group of treatment consists of firms which negotiate collectively the salaries and the counterfactual group is sought among firms where salaries are directly established by the employer. Formally, the treatment variable (coll_negociation) is written:

coll_negociation $=\left\{\begin{array}{l}1, \text { if firms negotiate collectively wages } \\ 0, \text { otherwise }\end{array}\right.$

Our performance variable (volunt_departure) is given by the fact that during 2006 the firm is concerned by voluntary departures. This variable can be written as follows:

volunt_departure $=\left\{\begin{array}{l}1, \text { if the firm has voluntary departures in } 2006 \\ 0, \text { otherwise }\end{array}\right.$

We take into account the following matching criteria: industry, firm size, geographical region of implementation, ownership, firm legal type, evaluation in terms of performance of the workforce, and firm size variation rate. These variables were presented in Section 3.

\section{Results}

In the first step of the econometric strategy, we estimate the probability for a firm to negotiate collectively wages with a probit regression, by introducing the matching variables presented in Section 4. The distribution of the observed matching criteria is given in Table 1.

As at least one of the modalities of each variable is significant at $10 \%$, we decided to keep all of the modalities. The probit model helps estimating the propensity score for each firm and allows for constructing counterfactuals. These models require a sufficiently important common support. $32 \%$ of firms which negotiate collectively wages have an estimated probability to negotiate collectively wages lower than 0.5 , and conversely $22 \%$ of firms that do not negotiate their salaries have a probability of bargaining higher than 0.5 . The supports of these two distributions largely overlap. Moreover, as the number of the establishments that did not negotiate their wages is higher, pairing is possible. The results of the probit estimation are described in Table 2. 


\begin{tabular}{|c|c|c|c|}
\hline Variable & $\begin{array}{l}\text { Global } \\
\text { sample }\end{array}$ & $\begin{array}{c}\text { Sample where } \\
\text { Coll_negotiation = } 1\end{array}$ & $\begin{array}{c}\text { Sample where } \\
\text { coll_negotiation }=0\end{array}$ \\
\hline Negotiate collectively wages (yes/no) & 49.3 & 100 & 0 \\
\hline \multicolumn{4}{|l|}{ Industry } \\
\hline Agriculture & 5.24 & 5.7 & 4.79 \\
\hline Extractive industry & 2.55 & 3.63 & 1.51 \\
\hline Manufacturing industry & 49.94 & 51.55 & 48.36 \\
\hline Electricity, gas and water supply industry & 3.7 & 5.96 & 1.51 \\
\hline Construction & 8.56 & 7.77 & 9.32 \\
\hline Trade & 9.58 & 8.81 & 10.33 \\
\hline Hotels and restaurants & 3.45 & 3.37 & 3.53 \\
\hline Transports & 8.05 & 6.99 & 9.07 \\
\hline Financial intermediation, real estate activities, etc. & 7.41 & 4.66 & 10.08 \\
\hline Other services & 1.53 & 1.55 & 1.51 \\
\hline \multicolumn{4}{|l|}{ Firm size } \\
\hline Between 10 and 20 employees & 12.01 & 7.77 & 16.12 \\
\hline Between 21 and 49 employees & 22.99 & 17.1 & 28.72 \\
\hline Between 50 and 249 employees & 34.74 & 33.42 & 36.02 \\
\hline 250 employees and more & 30.27 & 41.7 & 19.14 \\
\hline \multicolumn{4}{|l|}{ Region } \\
\hline North-East region & 13.67 & 16.58 & 10.83 \\
\hline West region & 14.69 & 14.25 & 15.11 \\
\hline North-West region & 11.75 & 4.92 & 18.39 \\
\hline Centre region & 5.87 & 8.03 & 3.78 \\
\hline South-East region & 13.67 & 12.18 & 15.11 \\
\hline South-Muntenia region & 13.41 & 16.84 & 10.08 \\
\hline Bucharest-Ilfov region & 14.69 & 14.51 & 14.86 \\
\hline South-West-Oltenia region & 12.26 & 12.69 & 11.84 \\
\hline \multicolumn{4}{|l|}{ Firm ownership } \\
\hline Private firm with full Romanian capital & 71.9 & 66.58 & 77.08 \\
\hline Private firm with full foreign capital & 8.3 & 8.29 & 8.31 \\
\hline Private firm with majority Romanian capital & 4.85 & 3.11 & 6.55 \\
\hline Private firm with majority Romanian capital and the rest belonging to the state & 0.89 & 1.04 & 0.76 \\
\hline Private firm with majority foreign capital & 6.26 & 6.74 & 5.79 \\
\hline Public firm with full state capital & 6.51 & 11.92 & 1.26 \\
\hline Public firm with majority state capital & 1.28 & 2.33 & 0.25 \\
\hline \multicolumn{4}{|l|}{ Firm legal type } \\
\hline Limited liability company & 52.62 & 35.23 & 69.52 \\
\hline Stock company & 43.3 & 59.59 & 27.46 \\
\hline Other form & 4.09 & 5.18 & 3.02 \\
\hline \multicolumn{4}{|l|}{ Firm size variation rate between 2004 and 2005} \\
\hline Firm size decreased & 33.84 & 41.71 & 26.20 \\
\hline Firm size remained still & 27.08 & 25.65 & 28.46 \\
\hline Firm size increased & 35.89 & 29.27 & 42.32 \\
\hline \multicolumn{4}{|l|}{ Evaluating the performances of the workforce } \\
\hline Does not evaluate the performance of its workers & 36.27 & 25.65 & 46.6 \\
\hline Evaluates the performance for wage reasons & 27.59 & 26.94 & 28.21 \\
\hline Evaluates the performance for job promotion reasons & 5.36 & 7.25 & 3.53 \\
\hline Evaluates the performance for both wage and job promotion reasons & 29.5 & 38.08 & 21.16 \\
\hline Other reasons & 1.28 & 2.07 & 0.5 \\
\hline Voluntary departures (yes/no) & 34.1 & 39.38 & 28.97 \\
\hline Number of observations & 783 & 386 & 397 \\
\hline
\end{tabular}

Table 1: Descriptive statistics

Among control variables, we introduced firm size because we consider that it is a main determinant of the retained strategy regarding wage bargaining. We observe that the probability of wage bargaining increases with firm size. We also introduce sector levels to capture differences in the wage negotiation implementation: 
Wage Collective Bargaining and Employee Voluntary Quits: A Romanian Empirical Analysis

\begin{tabular}{|c|c|c|c|}
\hline Variable & Estimation & Standard error & \\
\hline Intercept & 0.06 & 0.29 & Ns \\
\hline \multicolumn{4}{|l|}{ Industry } \\
\hline Agriculture & \multicolumn{3}{|c|}{ Ref. } \\
\hline Extractive industry & -0.38 & 0.42 & Ns \\
\hline Manufacturing industry & -0.38 & 0.23 & * \\
\hline $\begin{array}{l}\text { Electricity, gas and water } \\
\text { supply industry }\end{array}$ & -0.41 & 0.43 & Ns \\
\hline Construction & -0.39 & 0.28 & Ns \\
\hline Trade & -0.32 & 0.27 & $\mathrm{Ns}$ \\
\hline Hotels and restaurants & -0.20 & 0.34 & Ns \\
\hline Transports & -0.53 & 0.28 & * \\
\hline Financial intermediation, real estate activities, etc. & -0.58 & 0.29 & ** \\
\hline Other services & -0.60 & 0.46 & Ns \\
\hline \multicolumn{4}{|l|}{ Firm size } \\
\hline Between 10 and 20 employees & -0.42 & 0.17 & *** \\
\hline Between 21 and 49 employees & -0.24 & 0.13 & * \\
\hline Between 50 and 249 employees & \multicolumn{3}{|c|}{ Ref. } \\
\hline 250 employees and more & 0.23 & 0.14 & * \\
\hline \multicolumn{4}{|l|}{ Region } \\
\hline North-East region & -0.04 & 0.19 & Ns \\
\hline West region & -0.45 & 0.19 & *** \\
\hline North-West region & -1.40 & 0.22 & $* * *$ \\
\hline Centre region & 0.13 & 0.26 & Ns \\
\hline South-East region & -0.44 & 0.19 & $* *$ \\
\hline South-Muntenia region & \multicolumn{3}{|c|}{ Ref. } \\
\hline Bucharest-llfov region & -0.38 & 0.18 & $* *$ \\
\hline South-West-Oltenia region & -0.39 & 0.20 & ** \\
\hline \multicolumn{4}{|l|}{ Firm ownership } \\
\hline Private firm with full Romanian capital & \multicolumn{3}{|c|}{ Ref. } \\
\hline Private firm with full foreign capital & 0.02 & 0.18 & Ns \\
\hline Private firm with majority Romanian capital & -0.55 & 0.25 & ** \\
\hline Private firm with majority Romanian capital and the rest belonging to the state & -0.44 & 0.54 & Ns \\
\hline Private firm with majority foreign capital & -0.11 & 0.21 & Ns \\
\hline Public firm with full state capital & 0.87 & 0.32 & $* * *$ \\
\hline Public firm with majority state capital & 1.08 & 0.61 & * \\
\hline \multicolumn{4}{|l|}{ Firm legal type } \\
\hline Limited liability company & \multicolumn{3}{|c|}{ Ref. } \\
\hline Stock company & 0.63 & 0.12 & $* * *$ \\
\hline Otherform & 0.12 & 0.28 & Ns \\
\hline \multicolumn{4}{|l|}{ Firm size variation rate between 2004 and 2005} \\
\hline Firm size decreased & 0.42 & 0.13 & $* * *$ \\
\hline Firm size remained still & 0.06 & 0.12 & Ns \\
\hline Firm size increased & \multicolumn{3}{|c|}{ Ref. } \\
\hline \multicolumn{4}{|l|}{ Evaluating the performances of the workforce } \\
\hline Does not evaluate the performance of its workers & \multicolumn{3}{|c|}{ Ref. } \\
\hline Evaluates the performance for wage reasons & 0.22 & 0.12 & * \\
\hline Evaluates the performance for job promotion reasons & 0.67 & 0.24 & $* * *$ \\
\hline Evaluates the performance for both wage and job promotion reasons & 0.54 & 0.13 & $* * *$ \\
\hline Other reasons & 1.08 & 0.50 & ** \\
\hline Max-rescaled R-Square & \multicolumn{3}{|c|}{0.35} \\
\hline Number of observations & \multicolumn{3}{|c|}{783} \\
\hline
\end{tabular}

Table 2: Determinants of the probability of negotiating collectively wages

wage bargaining is mainly used in specific sectors. The agriculture sector is taken as the reference. Manufacturing, transport and financial intermediation and estate activities firms have a lower wage bargaining propensity than agriculture firms. Localization in different Romanian regions, ownership and firm legal type are 
other determinants of the wage bargaining process. The South-Muntenia region is taken as the reference. Excepting the North-East and the Centre regions, for the other firms the propensity of negotiating wages collectively is less important than for firms located in South-Muntenia. Private firms with majority Romanian capital have a lower probability of wage bargaining than private firms with full Romanian capital. As for public firms with full or majority state capital, they have a more significant probability of negotiating wages. This indicates that wage negotiation is more predominant for public firms. Concerning the legal type of the firm we can observe that stock companies have a more significant probability of wage bargaining compared to limited liability companies.

Regarding the firms' economic performance, we introduce an indicator describing firm size variation rate. Firms with a decrease in their size from 2004 to 2005 have more chances to negotiate salaries collectively than firms for which the size increased. Because the evaluation of workforce performance can describe the internal tensions inside the firm, it is important to take this information into account. Globally, evaluating the performances of the workforce increases the probability for a firm to negotiate wages collectively.

Table 3 presents the results of the estimation of our performance variable. This is the second step of the model. The comparison between firms that do not negotiate their wages collectively and firms that bargain over wages yields the following result: the probability that a firm negotiates wages collectively increases significantly (at 10\%) the probability of employee voluntary departures inside the firm. Hence wage bargaining firms increase by 8 percentage points the probability that they will experience voluntary departure of their employees. We can interpret this result as supporting the non-existence of a voice effect through the scope of collective bargaining in the Romanian industrial relations system. This result must be interpreted with caution. The effect is positive and weakly significant $(10 \%)$. It might change if we control for more firm characteristics and employees' characteristics (wages, occupations, etc.). Table 1 gives the result for the naive estimation: the difference of average voluntary quits for firms which negotiate wages collectively and for firms which do not negotiate wages collectively. This naive estimator emphasizes an increase of 10 points of percentage in voluntary quit behaviour (39.38-28.97). Without controlling for the selection bias associated to the wage collective negotiation, the effect is stronger. The comparison between the naive estimator and the kernel estimator proves the existence of a selection bias (controlled by our econometric strategy).

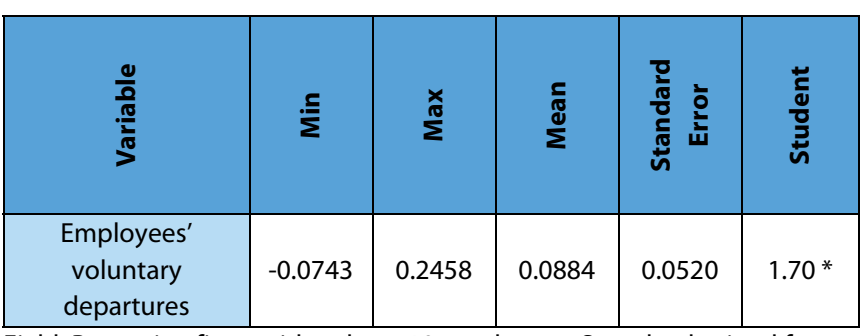

Field: Romanian firms with at least 10 employees. Sample obtained from a file produced by the Economic and Social Council of Romania in collaboration with the Romanian Ministry of Labour, Social Solidarity and Family

Note: * indicates significance at $10 \%$.

Table 3: Kernel propensity score estimator

To assess the matching quality we used several tests. They are directly implemented under Stata. First, we use a stratification test. It is proposed by Dejehia and Wahba $(1999,2002)$. The pscore program written by Becker and Ichino (2002) has an algorithm which implements it. Dehejia and Wahba divide observations into strata based on the estimated propensity score such that no statistically significant difference between the mean of the estimated propensity score in both treatment and control group remain. Then they use t-tests within each stratum to test if the distribution of the observable explanatory variables is the same between both groups. For this test, the region of common support is [0.0472842, 0.99084989]. The test indicates that dividing the propensity score distribution into five blocks ensures that the mean propensity score is not different for treated and controls in each block. In our case the balancing property is satisfied. A balancing test checks if the two groups (the treated and their counterfactuals) "look the same" in terms of the variables of the vector $X$ after the matching on the propensity score. In other words, we tested for equality of each covariate mean between groups within strata of the propensity score.

Second, we use the pstest procedure (Leuven and Sianesi, 2003). This test comes originally from Rosenbaum and Rubin (1985) and relies on the examination of standardized differences. The pstest procedure calculates several measures of the balancing of the variables in $X$ before and after matching. In particular, for each covariate it calculates two statistics. On the one hand, it calculates t-tests for equality of means in the treated and 
non-treated groups, both before and after matching. Ttests are based on a regression of the variable on a treatment indicator. On the other hand, it calculates the standardized bias before and after matching, together with the achieved percentage reduction in terms of absolute bias. The standardized bias is the difference of the sample means in the treated and non-treated (full or matched) sub-samples as a percentage of the square root of the average of the sample variances in the treated and non-treated groups (formulae from Rosenbaum and Rubin, 1985). In most empirical studies a bias reduction below $3 \%$ or $5 \%$ is seen as sufficient. In our sample, there is a multitude of values superior to $60 \%$. Hence we can conclude that our model specification is good. As expected, after matching covariates are balanced in both groups we found no significant difference.

Third, as a complement to this test we also use the psgraph programme which was also developed by Leuven and Sianesi (2003). Figure 1 illustrates the distribution of the propensity score for the treated and for the untreated. It emphasizes a good overlapping.

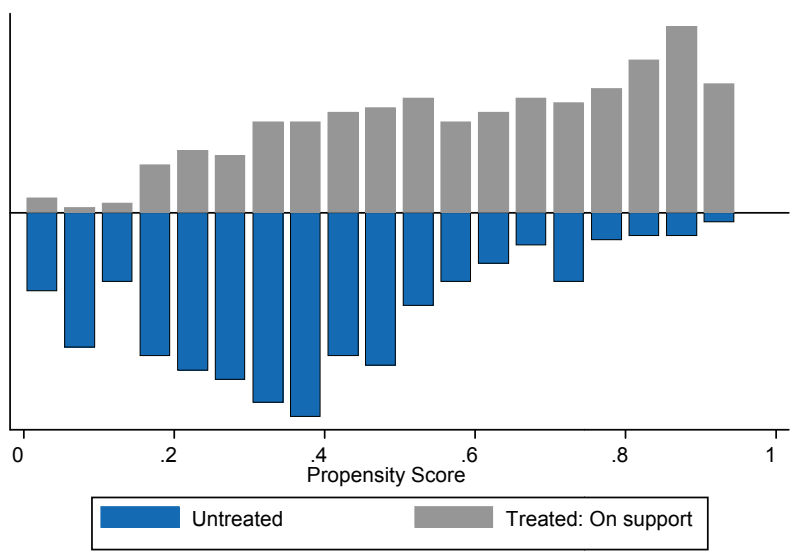

Field: Romanian firms with at least 10 employees. Sample obtained from a file produced by the Economic and Social Council of Romania in collaboration with the Romanian Ministry of Labour, Social Solidarity and Family

Note: we used the Stata psgraph program (Leuven and Sianesi, 2003).

Figure 1: Propensity score

\section{Conclusion}

In this paper we test Hirschman's "voice-exit" theory on the Romanian labour market. We control a possible selection bias associated with the fact that the wage bargaining process is not distributed randomly among firms. After implementing a kernel matching estimator we find a positive relationship between wage bargaining and employees' voluntary quits within Romanian firms. Nevertheless, this relationship is weakly significant (at $10 \%)$. This result is contrary to the findings of empirical studies implemented on developed countries. The Romanian labour market is fundamentally different from labour markets in developed countries. We also study a very particular year (2006), just before Romania's entrance into the European Union. In 2006, significant efforts were made by the whole Romanian economy in order to align itself with EU standards. For this reason, Romania obtained very good economic results in 2006. In this context, employees are most interested in good job opportunities (especially in terms of wages) rather than job stability. Hence our result may also hide some "inefficiency" in dealing with the collective negotiation process at this precise moment. As Meardi (2007) suggests for Central Eastern European countries, in Romania we could be witness to a strong "exit" phenomenon which might be followed by a "voice" phenomenon. Further research should be done after the entrance of Romania into the EU, as we would like to analyze if the "voice-exit" strategy changed after 2007. ‥

\section{References}

Aro, P., Repo, P. 1997. "Trade Union Experiences in Collective Bargaining in Central Europe", Budapest, ILO-CEET.

Backes-Geller, U., Frick, B., Sadowski, D. 1997. "Codetermination and Pesonnel Policies of German Firms: The Influence of Works Councils on Turnover and Further Training", International Journal of Human Resource Management, 8(3): 328-47.

Batt, R., Colvin, A., Keefe, J. 2002. "Employee Voice, Human Resource Practices, and Quit Rates: Evidence from the Telecommunications Industry", Industrial and Labor Relations Review, 55(4): 573-93.

Cappelli, P., Neumark, P. 2004. "External Churning and Internal Flexibility: Evidence of the Functional Flexibility and Core-Periphery Hypotheses", Industrial Relations, 43(1): 148-82.

Clarke, L., Cremers, J., Janssen, J. 2003. "EU Enlargement Construction Labour Relations as a Pilot", London, Reed Business Information.

Delery, J.E., Gupta, N., Shaw, J., Jenkins, G.D., Ganster, M. 2002. "Unionization, Compensation, and Voice Effects on Quits and Retention", Industrial Relations, 39(4): 625-46.

Doellgast, V. 2008. "Collective Bargaining and High-Involvment Management in Comparative Perspective: Evidence from U.S. and German Call Centers", Industrial Relations, Vol. 47, No.2, April.

Freeman, R.B. 1980. "The Exit-Voice Tradeoff in the Labor Market: Unionism, Job Tenure, Quits and Separations", Quarterly Journal of Economics, 94(3): 643-73.

Freeman, R.B., Medoff, J.L. 1984. What Do Unions Do? New York, Basic Books.

Frick, B. 1996. "Co-determinantion and personnel turnover: the German experience", Labour, 10: 407-30. 
Garcia-Serrano, C., Malo, M.A. 2002. "Worker Turnover, Job Turnover and Collective Bargaining in Spain", British Journal of Industrial Relations, 40:1, March, pp. 69-85.

Greskovits, B. 1998. The Political Economy of Protest and Patience. East European and Latin American Transformations Compared, Budapest, Central European University.

Heckman., J., Ichimura, H., Todd, P. 1998. "Matching as an econometric evaluation estimator", Review of Economic Studies, 65(2):261-294.

Hirschman, A. 1970. Exit, Voice, and Loyalty: Responses to Decline in Firms, Organizations, and States, Cambridge, MA, Harvard University Press.

Leuven, E., Sianesi, B. 2003. "PSMATCH2: Stata module to perform full Mahalanobis and propensity score matching, common support graphing, and covariate imbalance testing". http://ideas.repec.org/c/boc/bocode/s432001.html.

Meardi, G. 2007. "More voice after more exit? Unstable industrial relations in Central Eastern Europe", Indutrial Relations Journal, 38:6, 503523.

OECD 2004. "Chapter 2: Employment Protection Legislation and Labour Market Performance", OECD Employment Outlook.

Rosenbaum, P.R. Rubin, D. 1985. "Constructing a Control Group Using Multivariate Matched Sampling Methods that Incorporate the Propensity Score", The American Statistician, 39(1), 33-38.

Rubin, D. 1974. "Estimating causal effects of treatments in randomized and non-randomized studies", Journal of Educational Psychology, 66:688-701.

Trif, A. 2005. "Collective Bargaining Practices in Eastern Europe: Case Study Evidence from Romania", MPIfG Working paper, 05/9, October.

\section{Appendix 1: Definition of variables}

\begin{tabular}{|c|c|}
\hline Variable & Definition \\
\hline \multicolumn{2}{|c|}{ Dependent variables } \\
\hline $\begin{array}{l}\text { volunt_ } \\
\text { departure }\end{array}$ & $\begin{array}{l}\text { Employers appreciate that during } 2006 \\
\text { employees voluntarily left their firm } \\
\text { Dummy variable (=1 if yes) }\end{array}$ \\
\hline \multicolumn{2}{|c|}{ Independent variables } \\
\hline $\begin{array}{l}\text { coll_ } \\
\text { negociation }\end{array}$ & $\begin{array}{l}\text { Wages are established inside the firm by } \\
\text { collective bargaining Dummy variable ( }=1 \text { if } \\
\text { yes) }\end{array}$ \\
\hline size & $\begin{array}{l}\text { Four firm size dummy variables ( }=1 \text { if } 10 \text { to } \\
20 \text { employees; } 21 \text { to } 49 \text { employees; } 50 \text { to } \\
249 \text { employees; } 250 \text { employees and more) }\end{array}$ \\
\hline $\begin{array}{l}\text { geographical } \\
\text { location }\end{array}$ & $\begin{array}{l}\text { Eight dummy variables (=1 if the North-East } \\
\text { region, the West region, the North-West } \\
\text { region, the Centre region, the South-East } \\
\text { region, the South-Muntenia region, the } \\
\text { Bucharest-Ilfov region and the South-West- } \\
\text { Oltenia region) }\end{array}$ \\
\hline ownership & $\begin{array}{l}\text { Seven dummy variables ( }=1 \text { if private firm } \\
\text { with full Romanian capital, private firm with } \\
\text { full foreign capital, private firm with } \\
\text { majority Romanian capital, private firm with } \\
\text { majority Romanian capital and the rest } \\
\text { belonging to the state, private firm with }\end{array}$ \\
\hline
\end{tabular}

\begin{tabular}{|c|c|}
\hline & $\begin{array}{l}\text { majority foreign capital, public firm with full } \\
\text { state capital and public firm with majority } \\
\text { state capital) }\end{array}$ \\
\hline legal type & $\begin{array}{l}\text { Three dummy variables }(=1 \text { if limited } \\
\text { liability company, stock company and other } \\
\text { forms) }\end{array}$ \\
\hline $\begin{array}{l}\text { firm size } \\
\text { variation rate }\end{array}$ & $\begin{array}{l}\text { Three dummy variables indicating if the size } \\
\text { of the firm increased between } 2004 \text { and } \\
\text { 2005: yes, no and it remained the same }\end{array}$ \\
\hline $\begin{array}{l}\text { workforce } \\
\text { performance } \\
\text { evaluation }\end{array}$ & $\begin{array}{l}\text { Five dummy variables }(=1 \text { if the firm does } \\
\text { not evaluate the performance of its workers, } \\
\text { evaluates the performance for wage } \\
\text { reasons, evaluates the performance for job } \\
\text { promotion reasons, evaluates the } \\
\text { performance for both wage and job } \\
\text { promotion reasons and other reasons) }\end{array}$ \\
\hline industry & $\begin{array}{l}\text { The main activity of the firm: } 10 \text { dummy } \\
\text { variables (=1 if agriculture; extractive } \\
\text { industry; manufacturing industry; electricity, } \\
\text { gas and water supply industry; construction; } \\
\text { trade; hotels and restaurants; transports; } \\
\text { financial intermediation, real estate } \\
\text { activities, research and development, } \\
\text { operational services and consultancy and } \\
\text { assistance and finally, other services } \\
\text { (community, social and personal service } \\
\text { activities, private households with } \\
\text { employed persons, education, health and } \\
\text { social work and extra-territorial } \\
\text { organizations)) }\end{array}$ \\
\hline
\end{tabular}

\section{Appendix 2: The eight main Romanian regions}

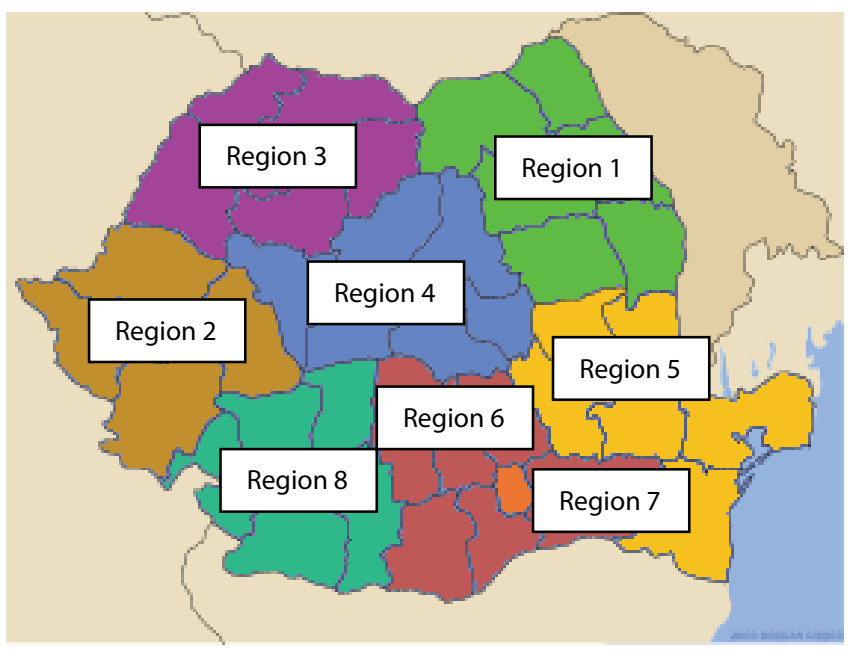

